\title{
Use of Cedrela odorata Linnaeus Exudate for Inhibiting Corrosion by Chlorides in Reinforced Concrete*
}

\author{
Modesto Barrios-Fontalvo ${ }^{\mathrm{a}}$ - Candelaria Tejada-Tovar ${ }^{\mathrm{b}}$ \\ - Ángel Villabona-Ortíz ${ }^{c}$. Fidel Castillo-Mercado ${ }^{d}$ \\ - Breiner Ramírez-Arenillae
}

\begin{abstract}
This paper evaluates the use of cedar tree exudate in chloride penetration and the probability of steel corrosion in reinforced concrete (RC), considering $0.3,0.5,0.7$, and $0.9 \%$ exudate by cement weight in the mixture at water/cement $(\mathrm{w} / \mathrm{c}$ ) ratios of 0.55 and 0.60 . Under these conditions, cylindrical specimens of 4 inches in diameter and 8 inches in height were constructed. The water-soluble chloride content of the extracted concrete powder was measured at 0.5, 1.0, and $2.0 \mathrm{~cm}$ depth according to ASTM C1218/C1218M, while the probability of corrosion was determined by measuring electric potentials with ASTM C876. A favorable incidence of $0.46 \%$ by weight of concrete was found when using $0.7 \%$ exudate at the $\mathrm{w} / \mathrm{c}$ ratio of 0.55 at the closest depth to the steel, compared to the $0.55 \%$ target. The probability of steel corrosion is reduced to $10 \%$ with potentials higher than $-0.2 \mathrm{~V}$ with more prolonged exposure to chlorides.
\end{abstract}

Keywords: Cedar gummy extract; concrete; steel; penetration; chlorides; corrosion

Received: 12/21/2019 Accepted: 04/21/2020

Available online: 09/12/2020

How to cite: M. Barrios-Fontalvo, C. Tejada-Tovar, Ángel Villabona-Ortíz, F. Castillo-Mercado, and B. Ramírez-Arenilla, "Use of Cedrela odorata Linnaeus Exudate for Inhibiting Corrosion by Chlorides in Reinforced Concrete", Cien.Ing.Neogranadina, vol. 30, no. 2, Jul. 2020.

* Research article.

a Especialista en Gerencia de Proyectos de Construcción. Universidad de Cartagena. Cartagena, Colombia. E-mail: mbarriosf@unicartagena.edu.co

b Magister en ingeniería ambiental, Universidad de Cartagena. Pregrado de la Universidad Industrial de Santander. Universidad de Cartagena, Cartagena, Colombia. E-mail: ctejadat@unicartagena.edu.co. ORCID: http://orcid.org/0000-0002-2323-1544

c Magister en ingeniería ambiental de la Universidad de Cartagena. Ingeniero químico Universidad Industrial de Santander en 1994. Docente del Departamento de Ingeniería Química de la Universidad de Cartagena. Universidad de Cartagena, Cartagena, Colombia. E-mail: avillabonao@unciartagena.edu.co. ORCID: https://orcid.org/0000-0001-8488-1076

d Ingeniero Civil, Universidad de Cartagena. Cartagena, Colombia. E-mail: castfm17@gmail.com

e Ingeniero Civil, Universidad de Cartagena. Cartagena, Colombia. E-mail: bramireza@unicartagena.edu.co 


\section{Uso del exudado de Cedrela odorata Linnaeus en la inhibición de la corrosión por cloruros en concreto reforzado}

Resumen: en este trabajo se evaluó el uso del exudado del árbol de cedro en la penetración de los cloruros y la incidencia de corrosión mediante ensayos de potencial eléctrico del acero en el concreto reforzado. Para esto, se evaluó el porcentaje de exudado en la mezcla de 0,3; 0,5; 0,7 y 0,9\% por peso de cemento, bajo relaciones agua/cemento (a/c) de 0,55 y 0,60. Se midió el contenido de cloruros solubles en agua del polvillo de concreto extraído a 0,5, 1,0 y 2,0 cm de profundidad de la probeta de acuerdo con la norma ASTM C1218/C1218M, mientras que la incidencia de corrosión se determinó a través de la medición de potenciales eléctricos con la norma ASTM C876. Hubo una incidencia favorable de 0,46\% por peso de concreto al emplear 0,7\% del exudado y una relación a/c 0,55 a la profundidad más cercana al acero respecto a 0,55 \% del blanco. La incidencia de corrosión del acero alcanzó a reducirse al $10 \%$ con potenciales mayores a -0,2 V.

Palabras clave: extracto gomoso de cedro; concreto; acero de refuerzo; cloruros; corrosión 


\section{Introduction}

Concrete is a material widely used in civil construction industries for its low cost and versatility regarding compressive stresses; however, under flexural, traction, shear, and torsion stress, it may show cracks and other mechanic faults [1]-[3]. For this reason, reinforcing steel is added to concrete, which provides it with mechanic properties and allows it to resist more substantial loads. Thus, the durability of such reinforced concrete (RC) determines the service life of structures concerning exposure to corrosive agents such as sulfates, chlorides, oxygen, among others, which deteriorate buildings physically, chemically, biologically, and structurally and affect the aesthetics of the structure [1], [4].

The deterioration of built RC infrastructure directly affects daily life in terms of safety, economy, and sustainability because the concrete produced is increasingly used for repair and rehabilitation rather than for new constructions [5]. Structural corrosion (sc) caused by the action of chloride ions is a global problem in terms of durability, especially in coastal/marine conditions, salty lakes, thaw salts, and other saline environments [6], [7]. Chloride-rich environments, fluctuations in the daytime and seasonal temperature and humidity, expansion-contraction and hydration-dehydration cycles that initiate and propagate reinforcement corrosion induce cracks, detachments, and loss of the load capacity of RC structures [8], [9]. When chlorides reach the surface of the steel reinforcement and accumulate, the passive layers $\left(\gamma-\mathrm{Fe}_{2} \mathrm{O}_{3}\right)$ of the steel brake, which substantially degrades the durability and useful life of RC structures and finally leads to considerable economic loss [10]. Thus, the costs associated with corrosion deterioration increase, which are
$3.4 \%$ of the global GDP, estimated in $\$ 3$ trillion per year [11], [12].

Different studies have been conducted around the integration of extracts, mucilage, or sap of trees and plants into concrete mixtures to counteract the corrosion of reinforcing steel [8], [9], [13]. Green corrosion inhibitors are widely found in nature and are presented as an economic and ecological solution; thus, satisfactory results have been obtained using extracts from the leaves, barks, seeds, fruits, and roots of plants [14]-[16]. In this sense, cedar has been used as a coating on steel, obtaining corrosion inhibitions of up to $46.4 \%$ [17]. Other elements that have been employed as anticorrosive agents include ginger extract [7], maize gluten meal [18], castor oil [19], cactus mucilage, marine brown algae, dehydrated cactus mucilage [20], apricot pomaces [15], Rhizophora mangle L. [9], [21], among others [22]-[25], because they contain compounds and functional groups that act as inhibitors of corrosive mechanisms. Therefore, the present article intends to evaluate the use of cedar exudate as an inhibitor of corrosion caused by the action of chlorides and the probability of steel corrosion in RC. For this, different exudate percentages in the mixture $(0.3,0.5,0.7$, and $0.9 \%)$ and water/ cement $(\mathrm{w} / \mathrm{c})$ ratios $(0.55$ and 0.60$)$ are used.

\section{Materials and Methods}

A multilevel factorial design was applied to the present study, taking as independent factors variations in the w/c ratio (0.55 and 0.60$)$ and the exudate percentage in the mixture by weight of cement $(0.3,0.5,0.7$, and $0.9 \%)$, as shown in Table 1. The response variables were chloride penetration depth and electric potentials of corrosion $\left(\mathrm{E}_{\text {corr }}\right)$. All experiments and measurements were taken in duplicate. 
Table 1. Experimental design

\begin{tabular}{|c|c|c|c|}
\hline \multicolumn{2}{|c|}{ FACTORS } & \multicolumn{2}{|c|}{ No. of Samples } \\
\hline $\begin{array}{l}\text { w/c } \\
\text { Ratio }\end{array}$ & $\begin{array}{l}\text { Exudate \% by } \\
\text { Weight of Cement }\end{array}$ & $\begin{array}{l}\text { Chloride } \\
\text { Penetration }\end{array}$ & $\mathrm{E}_{\text {corr }}$ \\
\hline \multirow{5}{*}{0.55} & 0.0 & 2 & 1 \\
\hline & 0.3 & 2 & 1 \\
\hline & 0.5 & 2 & 1 \\
\hline & 0.7 & 2 & 1 \\
\hline & 0.9 & 2 & 1 \\
\hline \multirow{5}{*}{0.60} & 0.0 & 2 & 1 \\
\hline & 0.3 & 2 & 1 \\
\hline & 0.5 & 2 & 1 \\
\hline & 0.7 & 2 & 1 \\
\hline & 0.9 & 2 & 1 \\
\hline \multicolumn{2}{|c|}{ Subtotal No. of Samples } & 20 & 10 \\
\hline \multicolumn{2}{|c|}{ Total No. of Samples } & 30 & \\
\hline
\end{tabular}

Source: Own elaboration.

Seventeen measurements were taken (one at zero time and the rest after each wetting- drying (w-D) cycle) to determine the probability of steel corrosion through the $\mathrm{E}_{\text {corr }}$, sampling each factor combination.

\section{Extraction of the Gummy Exudate}

The gummy exudate was extracted through an incision in the tree, and the material was collected 20 days later. It was dried in the sun for $48 \mathrm{~h}$, ground, and sieved [26].

\section{Samples}

Concrete cylinders of 4 inches in diameter and 8 in height, reinforced with $3 / 8$ " steel bars embedded in the center, were used for testing the electric potential of corrosion, as shown in Fig. 1.
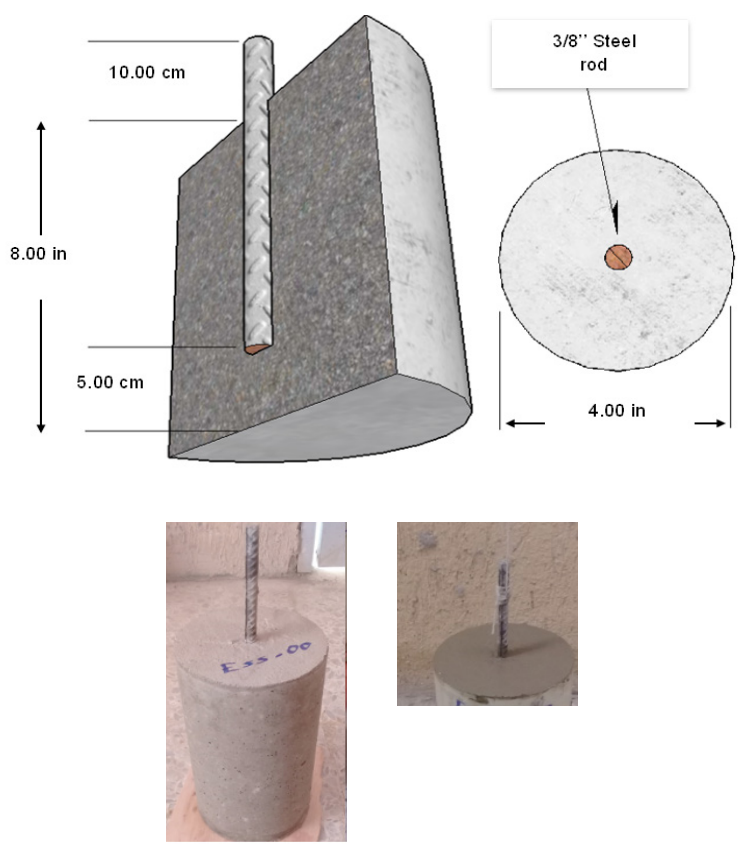

Fig. 1. Details of sample construction.

Source: Own elaboration.

Concrete mixes were prepared at a ratio of 1:2:2, a boulder of nominal size $3 / 4$ " and cement type I. Cedar exudate was added to the mixing water in percentages by weight of cement, according to Table 1.

\section{Exposure to Chlorides}

The specimens were exposed to W-D cycles, according to Table 2, partially immersing the cylinders in $3.53 \%$ saline solution to simulate the seawater in Cartagena de Indias [27] and equalizing the immersion and drying times for 90 days [9], [28].

Table 2. Duration of W-D cycles

$\begin{array}{lllll} & & \text { One Cycle } & \text { Start } & \text { End } \\ \text { Cycle } & \begin{array}{l}\text { Duration } \\ \text { (accumulated }\end{array} & \begin{array}{l}\text { (accumulated } \\ \text { days) }\end{array} \\ \text { Cycle } & \text { No. } & \text { (days) } & \text { days) } & \text { days }\end{array}$

$\frac{\frac{1: 1}{2: 2} \frac{4}{4: 4} \frac{5}{5: 5} \frac{4}{3} \frac{4}{10}}{\frac{8}{50 u}} \frac{\frac{2}{29}}{61} \frac{\frac{8}{28}}{\frac{60}{90}}$

Source: Own elaboration. 


\section{Chloride Penetration Depth}

After 90 days of w-D in saline solution, $20 \mathrm{~g}$ of pulverized concrete whose maximum size was 850 microns were taken by reaching with a hammer drill the radial distances of $0.5,1.0$, and 2.0 $\mathrm{cm}$ in each concrete cylinder. These samples were then analyzed to determine the water-soluble chloride content by weight of concrete following ASTM c1218/C1218M [29][30], thereby constructing chloride concentration vs. radial depth profiles.

\section{Electric Potentials of Corrosion}

The determination of the probability of steel corrosion through $\mathrm{E}_{\text {corr }}$ was achieved by applying ASTM c876 [31], [32]. Seventeen readings were taken, one in time zero and the rest after each W-D cycle, using an external $\mathrm{Cu} / \mathrm{CuSO}_{4}$ reference electrode connected to a high impedance multimeter. For each measurement, ten potentials were recorded around each sample, whose data were processed to obtain a representative value through the Grubbs test [33], [34]. Finally, scattered potential (V) vs. time (days) was plotted.

\section{Results and Discussion}

\section{Chloride Penetration Analysis}

Figs. 2 and 3 show the water-soluble chloride content profiles for each weight of concrete.

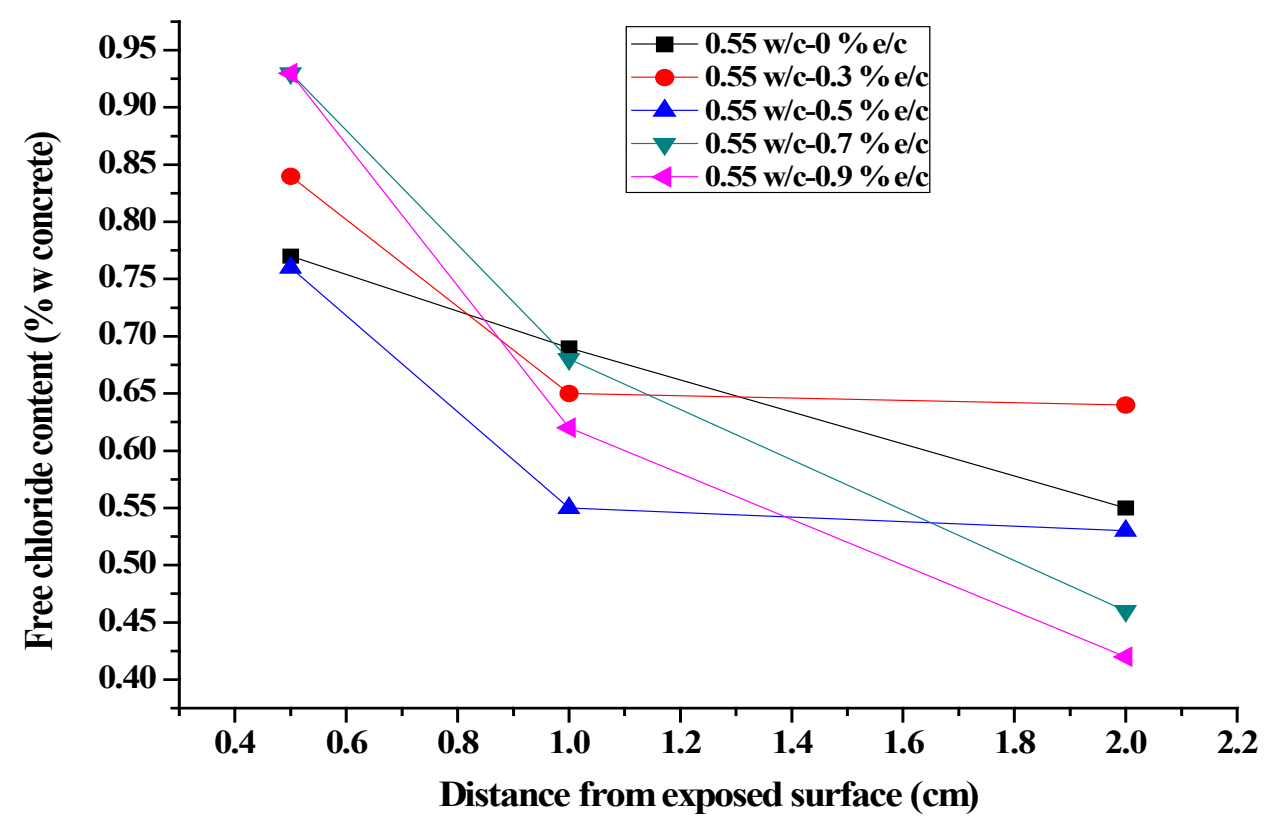

Fig. 2. Chloride penetration profile $(w / c$ ratio $=0.55)$.

Source: Own elaboration. 


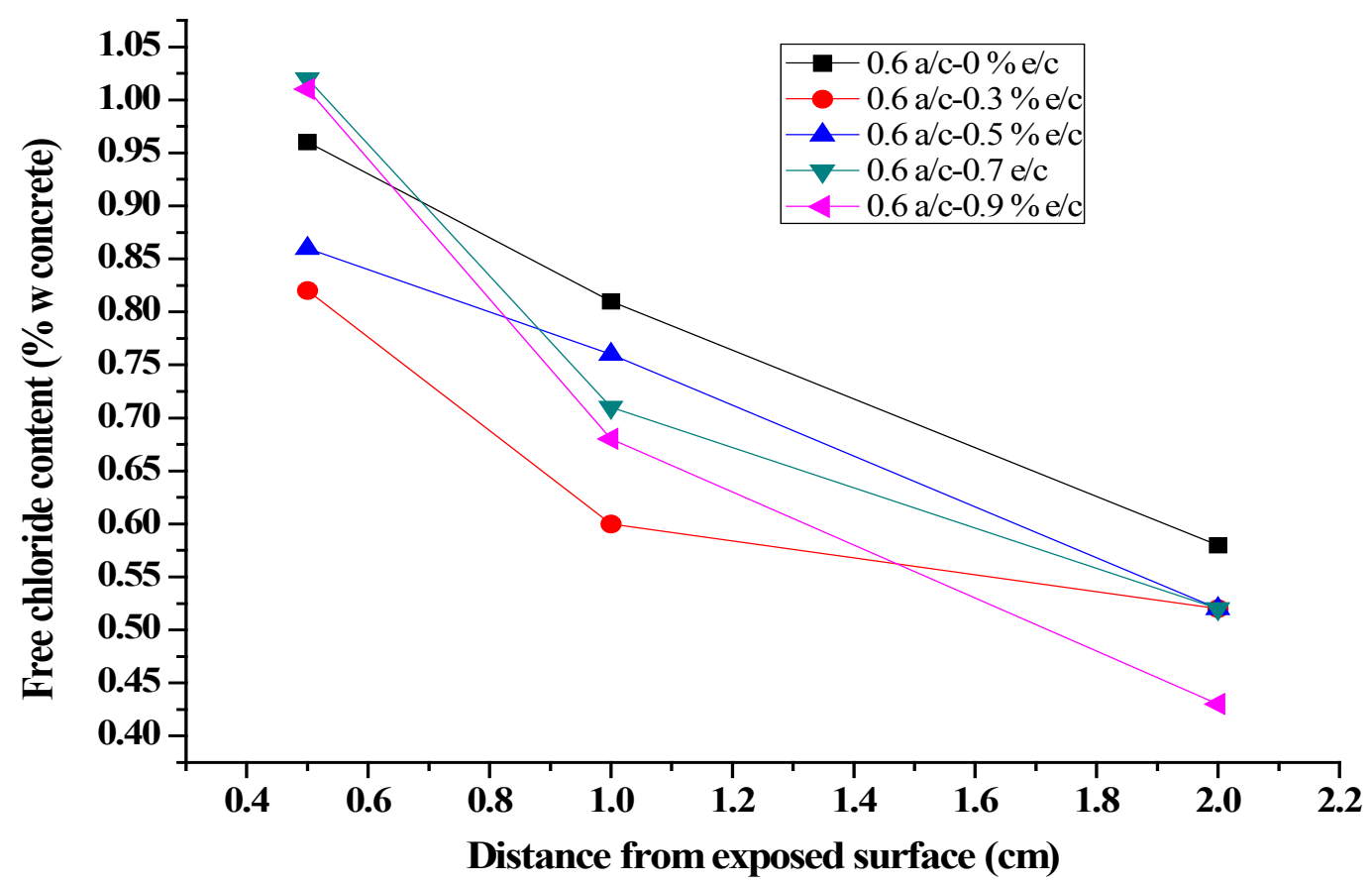

Fig. 3. Chloride penetration profile $(w / c$ ratio $=0.60)$.

Source: Own elaboration.

For the w/c ratio of 0.55 , in all cases, the chloride content by weight of concrete exceeded the limit of $0.15 \%$ recommended by NSR-10 [35], which could be the result of the aggressive submission of concrete specimens to chlorides. It was found that the concentration of $\mathrm{Cl}^{-}$using the w/c ratios of 0.55 and 0.6 is inversely proportional to the depth in the concrete, which is coherent with the diffusion theory [6], [18]. The target presented a linear behavior at greater depth, and the specimens prepared with the addition of exudate presented a non-linear behavior, the w/c ratio of 0.6 being the one that exhibited better behavior compared to the $\mathrm{w} / \mathrm{c}$ ratio of 0.55 .

For both ratios, when adding 0.7 and $0.9 \%$ exudate to concrete at the three evaluated depths, a decrease in the concentration of $\mathrm{Cl}^{-}$ions was observed as the cylinders deepened. For the w/c ratio of 0.55 with $0.3 \%$ exudate, an unfavorable performance was obtained, and using the $\mathrm{w} / \mathrm{c}$ ratio of 0.6 , the samples with 0.7 and $0.9 \%$ cedar exudate had the highest concentrations of chlorides at $0.5 \mathrm{~cm}$, exceeding $1 \%$. However, concentrations decreased to 1.0 and $2.0 \mathrm{~cm}$ compared to the target, getting the best results with a $\mathrm{Cl}^{-}$concentration of $0.43 \%$ with $0.9 \%$ exudate. The latter value is significant because the depth of $2.0 \mathrm{~cm}$ is the closest to the reinforcing steel. These results show that the addition of cedar exudate is an efficient alternative to mitigate corrosion and its effects on concrete reinforcements, thus increasing the useful life of structures.

It is observed that the free chloride content at each location grows with the increasing number of cycles, regardless of the type of mixture and the exposed condition, which can be explained 
by the cyclic W-D action resulting in a convective zone. Chloride concentration reaches a local maximum on the nearby surface and coincides with the chloride diffusion theory in which the depth influencing humidity is limited on the exposure surface, typically between 5 and $15 \mathrm{~mm}$ for concrete [36], [37]. Also, drying time can produce a highly concentrated solution in the pores and would be rapidly transported inward by capillary suction during the next wetting period [38]-[40].
Likewise, concrete samples containing pozzolans have significantly lower chloride content at different times, especially in deeper zones; this was previously reported by [41], [42].

\section{Probability of Steel Corrosion}

Figs. 4 and 5 show the variation of the electric potentials of RC specimens at w/c ratios of 0.55 and 0.6 vs. time in days, respectively.

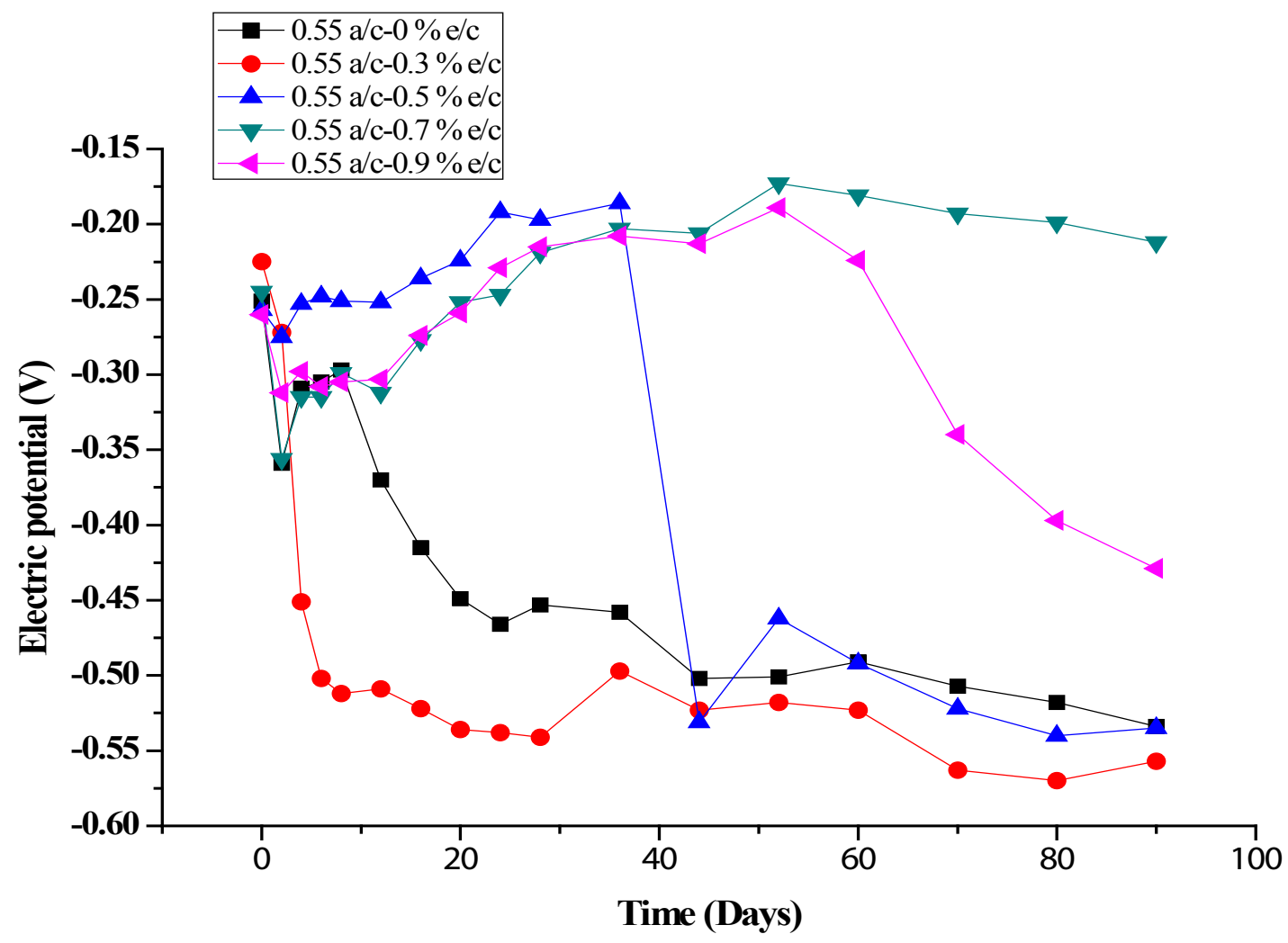

Fig. 4. Electric potentials of the concrete cylinder $(w / c$ ratio $=0.55)$.

Source: Own elaboration. 


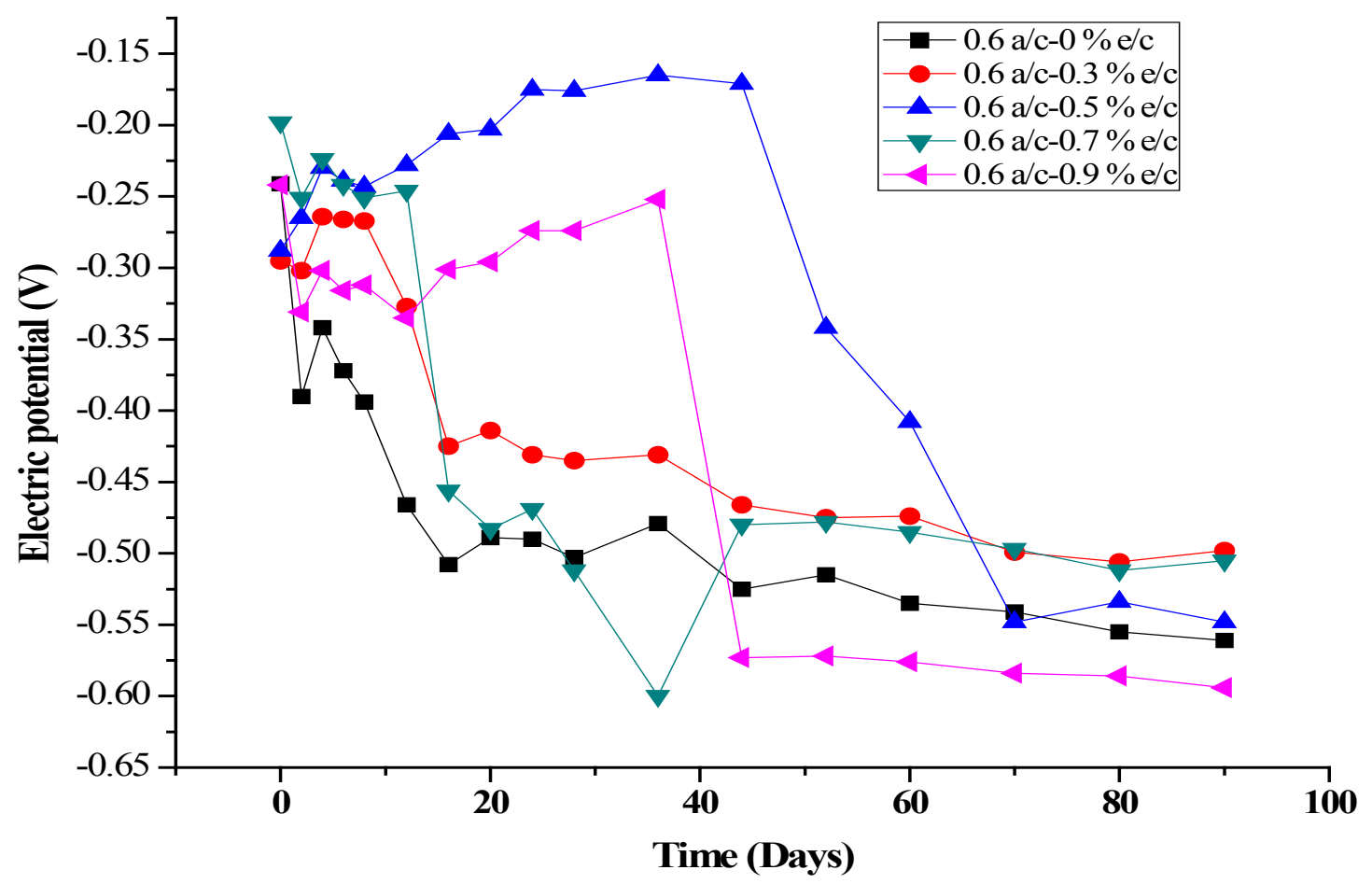

Fig. 5. Electric potentials of the concrete cylinder $(w / c$ ratio $=0.60)$

Source: Own elaboration.

It was found that all the potential values were lower than $-0.35 \mathrm{~V}$ using the w/c ratio of 0.55 , including the target, and that adding $0.3 \%$ exudate results in a $90 \%$ risk of early corrosion in the target. In contrast, the cylinders with the addition of $0.5,0.7$, and $0.9 \%$ exudate showed progressive increases in electric potential over time, reaching the lowest risk of corrosion with values higher than $-0.20 \mathrm{~V}$. It is noteworthy that with an addition of $0.9 \%$ exudate, the potential descends gradually until reaching $-0.397 \mathrm{~V}$ after 80 days, while with $0.7 \%$ it registered $-0.212 \mathrm{~V}$ after 90 days.

It is observed that the zero-day electric potential values of the concrete specimens using the w/c ratio of 0.6 ranged between -0.198 and $-0.295 \mathrm{~V}$ for concrete cylinders with 0.7 and $0.3 \%$ exudate, respectively, showing uncertainty in the possibility of steel corrosion. The target reaches the highest reinforcement corrosion risk zone after two days during the first W-D cycle with a potential of -0.392 $\mathrm{V}$, continuing with a tendency towards more negative values for the rest of the time of exposure to chlorides.

At the same time, the cylinders to which the exudate was added presented a favorable behavior at the beginning of the process, being the specimen with $0.5 \%$ the one that showed the most favorable trend, entering the risk zone after 60 days and achieving the least negative reading of 0.165 $\mathrm{V}$ after 36 days. Similarly, samples with $0.3,0.5$, and $0.9 \%$ showed tendencies to increase potential, recording a decrease after several w-D cycles, being specimens of 0.5 and 0.9 those which took longer to exceed the $-0.35 \mathrm{~V}$ threshold of the probability of corrosion. Regarding the specimen with $0.5 \%$ exudate, a potential of $-0.408 \mathrm{~V}$ was registered 60 
days after presenting the highest favorability upon reaching the lowest corrosion risk zone on day 20 . It also registered the least negative potential reading of the project, which was $-0.165 \mathrm{~V}$ after 36 days.

The trends observed in Figs. 4 and 5 show that the steel bars in the inhibition systems possibly received a complete passive film that can maintain well the state of the passive iron layers in the brackish solution at a concentration of $3.53 \% \mathrm{w} / \mathrm{v} \mathrm{NaCl}$. These results illustrate that gummy cedar extract has a corrosion inhibiting effect, probably due to the formation of an adsorption film on the original passive layer on the surface of the reinforcing bar, as well as inside the mixture, which restricts the cathodic reaction. This property could be provided by phenolic and limonoid constituents, such as flavonoids and proanthocyanidins [43], which are responsible for the formation of the film [44] During the corrosive activity of ions, the gummy extract inhibited concrete corrosion by limiting the anodic reaction, a mechanism also provided by ginger extract [7], castor oil [19], Arabic gum [45], guar gum [46], and other green inhibitors [22], [25], [47], [48].

For the 0.5 and $0.9 \%$ exudates by weight percentage of cement, the drop in electric potential after 30 days reveals that, during adsorption, the mass and charge of the extract molecules are transferred to the concrete surfaces and create a protective film on them. For a corrosion inhibitor to be considered efficient, the change in the $\mathrm{E}_{\text {corr }}$ value must range between $<85 \mathrm{mV}$ and $>85 \mathrm{mV}$ and represents either a mixed-type inhibitor or an anodic/cathodic-type inhibitor, respectively [49]. In the present study, the maximum changes in the $\mathrm{E}_{\text {corr }}$ value are $242 \mathrm{mV}$ for $0.5 \%$ exudate and 320 $\mathrm{mV}$ for $0.9 \%$, proving that the cedar extract molecule behaves as an anodic/cathodic-type inhibitor; therefore, it can be said that the anodic and cathodic reactions that do not vary due to active metallic sites are unblocked [50].

When comparing the target profile for 0.5 and $0.9 \%$, the passivation of the coated surface occurs significantly slower, which is shown by the decrease in the $\mathrm{E}_{\text {corr }}$ after 30 days. This phenomenon can be explained by the fact that the extract molecules do not form a uniform passive layer on the surface of the specimens [51]. The substantial drop in electric potentials after 30 days can be interpreted as an indication of the change in and activity of the passivating layer surface depending on time [52].

\section{Conclusions}

It was found that by adding 0.7 and $0.9 \%$ of the cedar exudate for both w/c ratios studied, the penetration of chlorides decreases. The probability of corrosion on steel embedded in concrete with $0.7 \%$ exudate at the w/c ratio of 0.55 after 90 days of exposure to chlorides is much lower. The probability of steel corrosion was reduced to $10 \%$ with potentials higher than $-0.2 \mathrm{~V}$. These results show that the addition of cedar exudate is an excellent alternative to mitigate corrosion and its effects on concrete reinforcements, thus extending the life of structures.

\section{Acknowledgments}

The authors would like to thank the University of Cartagena for providing the researchers with the time, chemicals, equipment, and software required to conclude this work successfully.

\section{References}

[1] R. Huza, "The durability and service life benefits of stainless steel rebar and the underpinning properties and features-A stainless industry primer for owners, planners, specifiers, and designers on the technical and market realities," in IABSE Symp. Rep., 2018, vol. 109 , no. 56 , pp. $880-887$.

[2] X. Shi, N. Xie, K. Fortune, and J. Gong, "Durability of steel-reinforced concrete in chloride environments: An overview," Constr. Build. Mater., vol. 30, pp. 12538, May 2012, doi: 10.1016/j.conbuildmat.2011.12.038

[3] M. Quraishi, D. Nayak, R. Kumar, and V. Kumar, "Corrosion of Reinforced Steel in Concrete and Its Control: An overview," J. Steel Struct. Constr., vol. 03, no. 01, pp. 1-6, 2017, doi: https://doi.org/10.4172/24720437.1000124

[4] A. M. Aguirre and R. Mejía de Gutiérrez, "Durabilidad del hormigón armado expuesto a condiciones agresivas,” Mater. Construcc., vol. 63, no. 309, pp. 7-38, Mar. 2013, doi: 10.3989/mc.2013.00313. 
[5] P. Zhang et al., "Steel reinforcement corrosion in concrete under combined actions: The role of freeze-thaw cycles, chloride ingress, and surface impregnation," Constr. Build. Mater., vol. 148, pp. 113 -121, Sep. 2017, doi: 10.1016/j.conbuildmat.2017.05.078

[6] R. Wattanapornprom and T. Ishida, "Modeling of chloride penetration into concrete under airborne chloride environmental conditions combined with washout effects," J. Adv. Concr. Technol., vol. 15, no. 3, pp. 126 -142, 2017, doi: doi.org/10.3151/jact.15.126

[7] Y. Liu et al., "Effect of ginger extract as green inhibitor on chloride-induced corrosion of carbon steel in simulated concrete pore solutions," J. Clean. Prod., vol. 214, pp. 298 -307, Mar. 2019, doi: 10.1016/j.jclepro.2018.12.299

[8] E. Alibakhshi, M. Ramezanzadeh, S. A. Haddadi, G. Bahlakeh, B. Ramezanzadeh, and M. Mahdavian, "Persian Liquorice extract as a highly efficient sustainable corrosion inhibitor for mild steel in sodium chloride solution," J. Clean. Prod., vol- 210, pp. 660 -672, Feb. 2019, doi: 10.1016/j.jclepro.2018.11.053

[9] J. O. Okeniyi, A. P. I. Popoola, and C. A. Loto, “Corrosion-inhibition and compressive-strength performance of Phyllanthus muellerianus and triethanolamine on steel-reinforced concrete immersed in saline/marine simulating-environment," Energy Procedia, vol. 119, pp. 972 -979, Jul. 2017, doi: 10.1016/j.egypro.2017.07.130

[10] C. Xiong et al., "Preparation of phytic acid conversion coating and corrosion protection performances for steel in chlorinated simulated concrete pore solution," Corros. Sci., vol. 139, pp. 275 -288, Jul. 2018, doi: 10.1016/j.corsci.2018.05.018

[11] M. G. Stewart and E. Bastidas-Arteaga, Corrosion of concrete and steel structures in a changing climate. Elsevier Inc., 2019.

[12] A. Castañeda, "Estudio de la corrosión atmosférica del acero de refuerzo embebido en el hormigón armado en La Habana," Ph.D. Dissertation, Inst. Sup. Politec. José Antonio Echeverría, Havana, Cuba, 2013.

[13] K. Nasr, M. Fedel, K. Essalah, F. Deflorian, and N. Souissi, "Experimental and theoretical study of Matricaria recutita chamomile extract as corrosion inhibitor for steel in neutral chloride media," Anti-Corros. Method. Mater., vol. 65, no. 3, pp. 292 -309, May 2018, doi: 10.1108/acmm-12-2017-1869
[14] I. Elmiziani, S. Houbairi, M. Essahli, S. Lhaloui, and A. Lamiri, "Lead corrosion inhibition by Cedrus atlantica as a green inhibitor in $0.1 \mathrm{M} \mathrm{Na} 2 \mathrm{CO} 3$ solution," Int. J. Adv. Chem., vol. 5, no. 1, p. 1, Jan. 2017, doi: 10.14419/ijac.v5i1.7115

[15] V. I. Vorobyova, M. I. Skiba, and I. M. Trus, "Apricot pomaces extract (Prunus armeniaca l.) as a highly efficient sustainable corrosion inhibitor for mild steel in sodium chloride solution,” Int. J. Corros. Scale Inhib., vol. 8, no. 4, Dec 2019, doi: 10.17675/2305-6894-20198-4-15

[16]W. Wang et al., "Employing ginger extract as an eco-friendly corrosion inhibitor in cementitious materials," Constr. Build. Mater., vol. 228, pp. 116713, Dec. 2019, doi: 10.1016/j.conbuildmat.2019.116713

[17] E. Quiñones, Y. Garcia, and W. Mendez, "Evaluación de la corrosión de acero de refuerzo frente al ambiente salino y ensayo preliminar de un ecoinhibidor para retardar el proceso corrosivo," in XIII Congr. Nac. Corros./IV Congr. Int. Mater. Integridad Estructural, ASCOR 2016, Jan. 2016.

[18] Z. Zhang, H. Ba, Z. Wu, and Y. Zhu, "The inhibition mechanism of maize gluten meal extract as green inhibitor for steel in concrete via experimental and theoretical elucidation," Constr. Build. Mater., vol. 198, pp. 208-298, Feb. 2019, doi: 10.1016/j.conbuildmat.2018.11.216

[19] S. P. Palanisamy, G. Maheswaran, A. G. Selvarani, C. Kamal, and G. Venkatesh, "Ricinus communis-A green extract for the improvement of anti-corrosion and mechanical properties of reinforcing steel in concrete in chloride media," J. Build. Eng., vol. 19, pp. 376-383, Sep. 2018, doi: 10.1016/j.jobe.2018.05.020

[20] E. F. Hernández, P. F. D. J. Cano-Barrita, F. M. León-Martínez, and A. A. Torres-Acosta, "Performance of cactus mucilage and brown seaweed extract as a steel corrosion inhibitor in chloride contaminated alkaline media," Anti-Corros. Method. Mater., vol. 64, no. 5, pp. 529-539, Sep. 2017, doi: 10.1108/acmm-022016-1646

[21] J. O. Okeniyi, C. A. Loto, and A. P. I. Popoola, "Rhizophora mangle L. Effects on steel-reinforced concrete in 0.5 M H2SO4: Implications for corrosion-degradation of wind-energy structures in industrial environments," Energy Procedia, vol. 50, pp. 429-436, 2014, doi: 10.1016/j.egypro.2014.06.052 
[22] Y. P. Asmara, T. Kurniawan, A. G. E. Sutjipto, and J. Jafar, "Application of plants extracts as green corrosion inhibitors for steel in concrete-A review," Indones. J. Sci. Technol., vol. 3, no. 2, pp. 158-170, Aug. 2018, doi: 10.17509/ijost.v3i2.12760

[23] R. Anitha, S. Chitra, V. Hemapriya, I. M. Chung, S. H. Kim, and M. Prabakaran, "Implications of eco-addition inhibitor to mitigate corrosion in reinforced steel embedded in concrete," Constr. Build. Mater., vol. 213, pp. 246-256, Jul. 2019, doi: 10.1016/j.conbuildmat.2019.04.046

[24] M. Ramezanzadeh, G. Bahlakeh, Z. Sanaei, and B. Ramezanzadeh, "Studying the Urtica dioica leaves extract inhibition effect on the mild steel corrosion in 1 $\mathrm{M} \mathrm{HCl}$ solution: Complementary experimental, ab initio quantum mechanics, Monte Carlo and molecular dynamics studies," J. Mol. Liq., vol. 272, pp. 120-136, Dec. 2018, doi: 10.1016/j.molliq.2018.09.059

[25] N. Raghavendra, "Latest Exploration on Natural Corrosion Inhibitors for Industrial Important Metals in Hostile Fluid Environments: A Comprehensive Overview," J Bio Tribo-Corros., vol. 5, no. 3, p. 54, 2019, doi: 10.1007/s40735-019-0240-X

[26] O. A. Adetunji and M. A. Odeniyi, "Material and Compression Properties of Cedrela odorata Gum Co-Processed with Plantain Starch and Microcrystalline Cellulose," Polim. Med., vol. 46, no. 1, pp. 35-43, 2016, doi: 10.17219/pim/64924

[27] R. Acevedo Barrios, "Diagnóstico preeliminar ambiental de playas de Cartagena de Indias, Caribe colombiano," Tek. Rev. Cient., vol. 17, no. 1, p. 38, Jul. 2017, doi: 10.25044/25392190.891

[28]A. Carvajal Guerra and F. Guzmán, "Estudio de aditivos inhibidores de corrosión para estructuras de hormigón armado. Análisis de potencial de corrosión,” Rev. Construcc., vol. 4, no. 2, pp. 25-29, Dec. 2005,

[29] N. P. Vaddey, M. Shakouri, and D. Trejo, "Predicting chloride testing outcome of different cementitious systems,” ACI Mater. J., vol. 117, no. 1, pp. 139-151, 2020.

[30] D. Meng, S. Lin, and H. Azari, "Nondestructive Corrosion Evaluation of Reinforced Concrete Bridge Decks with Overlays: An Experimental Study," J. Test. Eval., vol. 48, no. 1, pp. 516-537, Jan. 2020. Available: https://www.redalyc.org/pdf/1276/127619745003.pdf
[31] Frank E. Grubbs, "Procedures for Detecting Outlying Observations in Samples," Technometrics, vol. 11, no. 1, pp. 1-21, Feb. 1969, doi: 10.1080/00401706.1969.10490657

[32] F. E. Grubbs, "Sample Criteria for Testing Outlying Observations," Ann. Math. Stat., vol. 21, no. 1, pp. 2758, Mar. 1950, doi: 10.1214/aoms/1177729885

[33] Título C: Concreto estructural, NCR10-Reglamento Colombiano de Construcción Sismo Resistente, Asociación Colombiana de Ingeniería Sísmica, Colombia, 2010.

[34] C. Fu, H. Ye, N. Jin, and Y. Huang, "Chloride Penetration in Reinforced Concrete Beams under Combined Sustained Loading and Drying-Wetting Cycles," J. Mater. Civ. Eng., vol. 34, no. 2, p. 04020025, Apr. 2020, doi: 10.1061/(asce)mt.1943-5533.0003076

[35] H. Ye, C. Fu, N. Jin, and X. Jin, "Influence of flexural loading on chloride ingress in concrete subjected to cyclic drying-wetting condition," Comput. Concr., vol. 15, no. 2, pp. 183-198, Feb. 2015, doi: 10.12989/ cac.2015.15.2.183

[36] X. Gang, L. Yun-Pan, S. Yi-Biao, and X. Ke, "Chloride ion transport mechanism in concrete due to wetting and drying cycles," Struct. Concr., vol. 16, no. 2, pp. 289-296, Jun. 2015, doi: 10.1002/suco.201400035

[37] J. Cai, M. Li, Q. Chen, J. Lai, and M. Wei, "Chloride ingression in reinforced concrete beams subjected to flexural loading under cyclic drying-wetting condition,” J. Cent. South Univ. Sci. Technol., vol. 50, no. 11, pp. 2840-2850, 2019.

[38] H. Ye, X. Jin, C. Fu, N. Jin, Y. Xu, and T. Huang, "Chloride penetration in concrete exposed to cyclic drying-wetting and carbonation," Constr. Build. Mater., vol. 112, pp. 457-463, Jun. 2016, doi: 10.1016/j.conbuildmat.2016.02.194

[39] C. M. Ikumapayi, "Development of a short time model for predicting chloride ingress into normal and pozzolanic concrete," IOP Conf. Ser. Mater. Sci. Eng., vol. 640, no. 012113, Nov. 2019, doi: 10.1088/1757$899 \mathrm{x} / 640 / 1 / 012113$

[40] M. H. Tadayon, M. Shekarchi, and M. Tadayon, "Long-term field study of chloride ingress in concretes containing pozzolans exposed to severe marine tidal zone," Constr. Build. Mater., vol. 123, pp. 611-616, Oct. 2016, doi: 10.1016/j.conbuildmat.2016.07.074 
[41] S. D. R. Mariscal-Lucero, M. Rosales-Castro, V. Sánchez-Monsalvo, and J. A. Honorato-Salazar, "Evaluación de fenoles y limonoides en hojas de Cedrela odorata (Meliaceae) de una plantación experimental establecida en Tezonapa Veracruz, México," Rev. Biol. Trop., vol. 63, no. 2, pp. 545-558, Dec. 2014, doi: 10.15517/rbt.v63i2.15405

[42] L. Hou et al., "A Combined Inhibiting Effect of Sodium Alginate and Sodium Phosphate on the Corrosion of Magnesium Alloy AZ31 in $\mathrm{NaCl}$ Solution," J. Electrochem. Soc., vol. 163, no. 8, pp. C486-C494, 2016, doi: 10.1149/2.0941608jes

[43] A. Biswas, P. Mourya, D. Mondal, S. Pal, and G. Udayabhanu, "Grafting effect of gum acacia on mild steel corrosion in acidic medium: Gravimetric and electrochemical study," J. Mol. Liq., vol. 251, pp. 470-479, Feb. 2018, doi: 10.1016/j.molliq.2017.12.087

[44] M. Messali et al., "Guar gum as efficient non-toxic inhibitor of carbon steel corrosion in phosphoric acid medium: Electrochemical, surface, DFT and MD simulations studies," J. Mol. Struct., vol. 1145, pp. 43-54, Oct. 2017, doi: 10.1016/j.molstruc.2017.05.081

[45] I. Pradipta, D. Kong, and J. B. L. Tan, "Natural organic antioxidants from green tea form a protective layer to inhibit corrosion of steel reinforcing bars embedded in mortar," Constr. Build. Mater., vol. 221, pp. 351-362, Oct. 2019, doi: 10.1016/j.conbuildmat.2019.06.006
[46] S. A. Abdulsada and T. I. Török, "Studying effect of addition green inhibitor on compression strength of reinforced concrete," IOP Conf. Ser. Mater. Sci. Eng., vol. 613, no. 1, pp. 3-7, Nov. 2019, doi: 10.1088/1757$899 x / 613 / 1 / 012024$

[47] A. Mathina and R. Rajalakshmi, "Corrosion inhibition of mild steel in acid medium using Canna indica as green corrosion inhibitor,"rasayan J. Chem., vol. 9, no. 1, pp. 56-66, 2016. Available: http://rasayanjournal.co.in/vol-9/issue-1/9_Vol.9,\%20No.1,\%205666,\%20Jan.-March,\%202016,\%20RJC-1373.pdf

[48] M. Hegde and S. P. Nayak, "Aqueous extract of Dillenia Pentagyna Fruit as green inhibitor for mild steel corrosion in 0.5 M hydrochloric acid solution," J. Mater. Environ. Sci., vol. 10, no. 1, pp. 22-31, 2019. Available: https://www.jmaterenvironsci.com/Document/ vol10/vol10_N1/3-JMES-Hegde-2019.pdf

[49] D. B. Left, M. Zertoubi, S. Khoudali, and M. Azzi, "New application of Chamaerops humilis L. extract as a green corrosion inhibitor for reinforcement steel in a simulated carbonated concrete pore solution," Port. Electrochim. Acta, vol. 36, no. 4, pp. 249-257, 2018, doi: 10.4152/pea.201804249

[50] P. Dohare, D. S. Chauhan, and M. A. Quraishi, "Expired podocip drug as potential corrosion inhibitor for carbon steel in acid chloride solution," Int. J. Corros. Scale Inhib., vol. 7, no. 1, pp. 25-37, Feb. 2018, doi: 10.17675/2305-6894-2018-7-1-3 